九州大学学術情報リポジトリ

Kyushu University Institutional Repository

\title{
Pollen and spores from the perennial sea-ice covered environment of the central Arctic Ocean, summer 2004 (IODP ACEX 302)
}

Tsutsui, Hideto

Department of Earth and Planetary Sciences, Graduate School of Sciences, Kyushu University

Takahashi, Kozo

Department of Earth and Planetary Sciences, Graduate School of Sciences, Kyushu University

Fowell, Sarah J.

Department of Geology and Geophysics, University of Alaska Fairbanks

https://doi.org/10.5109/13526

出版情報: 九州大学大学院理学研究院紀要 : Series D, Earth and planetary sciences. 32 (2)， pp. 45-56, 2009-03-02. Faculty of Science, Kyushu University

バージョン :

権利関係 : 
Mem. Fac. Sci., Kyushu Univ., Ser. D, Earth \& Planet. Sci., Vol. XXXII, No. 2, pp. 45-56, March 2, 2009

\title{
Pollen and spores from the perennial sea-ice covered environment of the central Arctic Ocean, summer 2004 (IODP ACEX 302)
}

\author{
Hideto Tsutsui*, Kozo Takahashi* and Sarah J. Fowell ${ }^{* *}$
}

\begin{abstract}
We obtained three different types of samples from the central Arctic Ocean during the IODP Arctic Coring Expedition (ACEX) 302, which took place during summer 2004: they are (1) sea water, (2) sea-ice, and (3) diatom mat samples. A total of 227 specimens of pollen and spores as well as 52 pollen fragments were found in the samples. Dominant pollen taxa are vesiculate: Pinus (pines, "Matsu" in Japanese), Picea (spruce, "Touhi" in Japanese) and Abies (fir, "Momi" in Japanese). Porate pollen and monolete spores were also found, but their populations were very small. Most of the pollen grains encountered were from the sea water sample type, whereas in sea-ice or diatom mat samples pollen grains were very rare. It is most likely that these pollen grains were transported via the Arctic Current rather than via atmospheric pathways, such as the geostrophic wind.
\end{abstract}

Keywords: pollen, spores, central Arctic Ocean, Arctic Current, Pinus, Picea, Abies, ACEX

\section{Introduction}

A number of pollen studies have been performed around the Arctic Ocean. (e.g., McAndrews, 1984; Gajewski et al., 1995; Rousseau et al., 2005; Andreev et al., 2006; Carrie et al., in press). Pollen grains are very useful proxies for reconstructing past climatic changes (e.g., Shimoyama et al., 1995; Peck et al., 2002; Fowell et al., 2003). Because of their small size and density, they can sometimes travel long distances from production to burial in sediments (e.g., Heusser and Balsam, 1977, 1985; Kawahata and Ohshima, 2002; Rousseau et al., 2005). We have unexpectedly encountered sizable populations of pollen grains in the plankton samples obtained specifically for analysis of silicoflagellate and diatom populations in the central Arctic Ocean. All the sampled stations are located in remote areas far from surrounding continents and islands where pollen and spores are produced. Thus, the presence of pollen grains in the samples warrants an investigation to decipher their transport pathways via atmosphere and/or ocean currents. The objectives of the pollen study are the following: (1) document and list the taxa encountered; (2) characterize their relative abundances in the population; and (3) shed light on provenance and transport pathways.

Pollen grains recovered from sea water of the Arctic Ocean have the potential to provide important information regarding transport mechanisms and source supply areas. However, pollen

Manuscript received on 27 November 2008; accepted on 29 December 2008

* Department of Earth and Planetary Sciences, Graduate School of Sciences, Kyushu

University, Higashi-ku, Fukuoka 812-8581, JAPAN; hideto@geo.kyushu-u.ac.jp

** Department of Geology and Geophysics, University of Alaska Fairbanks, Box 755780 , Fairbanks AK 99775, USA. 
collection and sampling is very difficult and hazardous because this region is covered by sea-ice most of the year, and weather conditions are not constant. Under these difficult conditions, Takahashi et al. (in press) managed to collect sea water, sea-ice and diatom mat samples specifically targeted for plankton and ice algae from the central Arctic Ocean. These samples also included pollen grains which made this study possible. Furthermore, they are very important for understanding circulation behavior of water masses such as the Arctic Current and the advective processes of suspended particles derived from land (Schlosser et al., 1995).

Around the Arctic Ocean, the boreal forests provide high biodiversity for pollen and spores. In Russia, total tree biomass per area is 1.4 times higher than in Canada. Especially in Siberia, the carbon stocks per area (conversion from tree biomass) are ca. $5 \mathrm{~kg} \mathrm{~cm}^{-2}$ in Eastern Siberia and ca. $4 \mathrm{~kg} \mathrm{~cm}^{-2}$ in Far Eastern Siberia. In North America, Alaska represents ca. $2.5 \mathrm{~kg} \mathrm{~cm}^{-2}$ and the boreal forests in Canada represent ca. $2 \mathrm{~kg} \mathrm{~cm}^{-2}$ (Wirth, 2005). Major dominant tree taxa of the boreal forests in Asian Russia include Larix ("Karamatsu" in Japanese), Pinus, Picea, Abies, Betula ("Shirakaba" in Japanese), Populus (poplar, "Popula" or "Hakoyanagi" in Japanese), and Quercus ("Konara" in Japanese). Larix, Pinus, Picea, and Betula are the major contributors to the total carbon in millions of tons (Alexeyev et al., 2000). Thus, these taxa are most likely to be encountered in the Arctic samples.

The Arctic Current originates in the vicinity of the Bering Strait, which is located at $180^{\circ}$, and divides into two currents in the region of the Siberian end of the Lomonosov Ridge. One current flows along the ridge towards the North Pole and then continues through the Amundsen Basin towards Greenland. Another current flows along the Siberian side of the Nansen Basin and exits to the Norwegian Sea. The current flowing along the Lomonosov Ridge is further divided into two branches in the region close to the Greenland end of the ridge. A portion of this current circles clockwise through the Canada Basin before forming a gyre in the central Makarov Basin. The remainder flows through the Fram Strait into the Norwegian Sea (Aagaard et al., 1985: Fig. 1). In addition to the understanding of the surface water mass circulation, the behavior of the air mass circulation may also be important. The geostrophic wind flows with high intensity on the perimeter of the Arctic Ocean, but it does not generally flow over and across the central Arctic Ocean (Ganpo et al., 1982: Fig. 1).

\section{Samples and Methods}

Opportunities to sample sea water and sea-ice became available four times on board Swedish ice breaker R/V Oden during 12 August through 7 September 2004 during the Integrated Ocean Drilling Program (IODP) Arctic Coring Expedition (ACEX) 302. The four sampled locations were distributed between $87^{\circ} \mathrm{N}$ and the North Pole in the central Arctic Ocean (Table 1; Fig. 1). Since the central Arctic Ocean was in the pack ice condition, the sea-ice had to be broken by the ice breaker in order to generate open water space for water sampling. When the ship was stationary and open water was available next to the ship, the sampling was performed with a bucket, a weight, and a rope. Two-bucket samples (ca. 15 liters each) were collected to obtain ca. 30 liters of total sample volume. The samples included sea water on three occasions and sea-ice and diatom mat on two occasions each, respectively (Tables 1-2; Takahashi et al., in press).

Sea water samples were sieved through a $250 \mu \mathrm{m}$ stainless mesh prior to microslide preparation. Sea-ice samples mainly constituted relatively large sea-ice pieces (e.g., $>2-3 \mathrm{~cm}$ ) plus some pieces greater than $250 \mu \mathrm{m}$ in size. None of the sea water samples were treated with any chemicals, and hence the integrity of pollen morphology is preserved. Diatom mat samples collected on 12 and 14 August were treated with hydrogen peroxide because initially the main objective was to examine siliceous diatoms and silicoflagellates. Normally, pollen or spores with thin sporoderm tend to 
Table 1. Logistics of sample sites and conditions (Takahashi et al., in press).

\begin{tabular}{lrrrr}
\hline Date in 2004 & 12 August & 14 August & 25 August & 7 September \\
\hline Latitude & $87^{\circ} 03.2^{\prime} \mathrm{N}$ & $87^{\circ} 54.8^{\prime} \mathrm{N}$ & $87^{\circ} 56.0^{\prime} \mathrm{N}$ & $89^{\circ} 59.0^{\prime} \mathrm{N}$ \\
Longitude & $40^{\circ} 11.0^{\prime} \mathrm{E}$ & $138^{\circ} 32.6^{\prime} \mathrm{E}$ & $140^{\circ} 43.3^{\prime} \mathrm{E}$ & $63^{\circ} 11.9^{\prime} \mathrm{E}$ \\
Air temperature $\left({ }^{\circ} \mathrm{C}\right)$ & -1.6 & -0.4 & -1.5 & -8.2 \\
Water temperature $\left({ }^{\circ} \mathrm{C}\right)$ & -1.7 & -1.8 & -1.2 & -1.6 \\
Water depth (m) & 3550 & 1220 & 1172 & 4458 \\
Ice thickness Old/Fy: Average $(\mathrm{cm})$ & $150^{*}$ & $250 / 100$ & $120 / 200$ & $200 / 120$ \\
Ice thickness Old/Fy: Max $(\mathrm{cm})$ & $300^{*}$ & $300 / 150$ & $180 / 300$ & $400 / 180$ \\
\hline
\end{tabular}

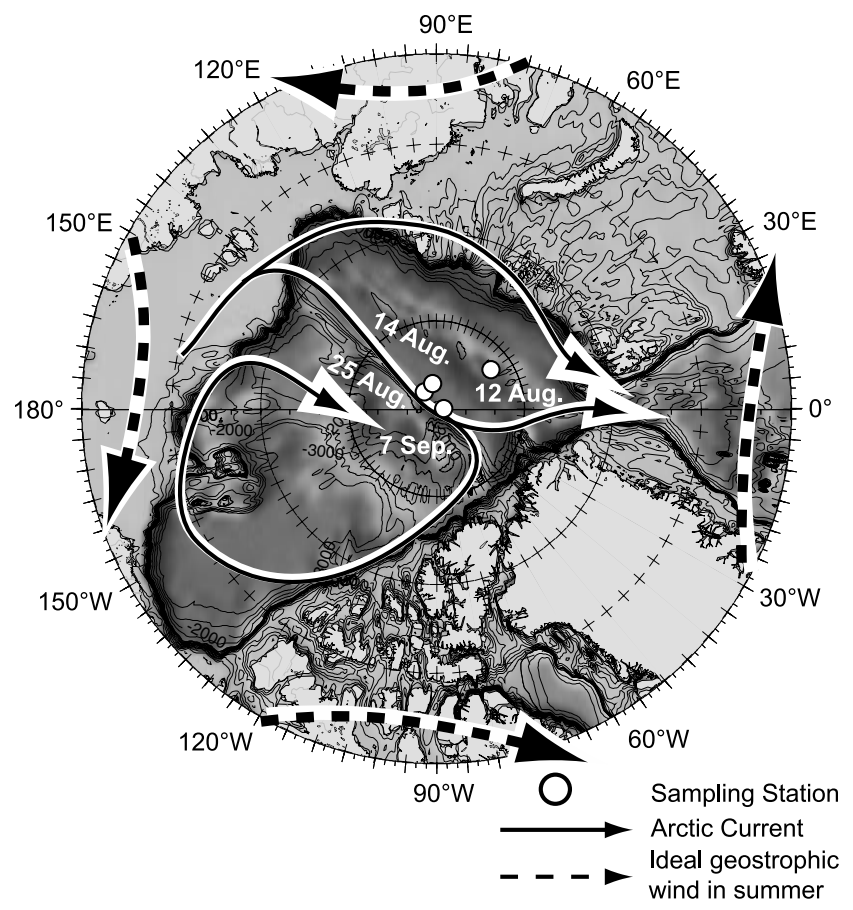

Fig. 1. Map showing sampled stations in the central Arctic Ocean together with possible pathways for the pollen grains and spores encountered, including the ocean currents and the summer geostrophic wind in the Northern Hemisphere. (Map is from the Collaborative Research Center (SFB) 574 site: http://www.ifm-geomar.de/).

shrink, deform or burst when treated with hydrogen peroxide.

Because the primary objective of the microslide preparation method was to observe siliceous frustules and skeletons of diatoms and silicoflagellates, we did not employ the standard glycerinjelly method for mounting pollen (e.g., Matsushita, 1993). Microslides were mounted with Mount Media ${ }^{\circledR}$ of the Wako Chemicals Co. Ltd. These were brought to a shore based laboratory for further analysis, and we were able to identify more than two hundred pollen and spore specimens.

The method for sample identification for types and dates follows that of Takahashi et al. (in press). That is, the sample types are designated as SW, SC, and DM for sea water, sea-ice, and diatom mat, respectively. The sample date and month follows the sample type and hence, for example, the sea water sample obtained on 14 August 2004 is designated as SW14Aug (Table 2). 
Table 2. Raw counts of pollen and spore taxa encountered in three different sample types from the central Arctic Ocean.

\begin{tabular}{lccccccc}
\hline & & Posiculate & Spore \\
\hline
\end{tabular}

\section{Results}

A total of 227 specimens of pollen and spore taxa were counted (Table 2) and the representative micrographs of the taxa are illustrated (Plates 1-2). The dominant pollen taxa are vesiculates: Among the taxa belonging to genus Pinus, Pinus pumila (Japanese stone pine or Siberian dwarf pine) dominates (Plate 1; Table 2; Fig. 2). Vesiculate fragments are second in abundance to the genus Pinus, followed by porate and colpate morphologies. Fourth in abundance is Picea (spruce). The least common vesiculate type is Abies (fir) (Plates 1-2; Table 2). Fragments of vesiculate grains were also counted separately in addition to intact specimens. Vesiculate pollen dominated the assemblages, comprising 52\% (excluding spores) of the total counts of all environments at all sampled stations. The remainder consists of porate and colpate pollen, including triporate types. Unidentified porate and colpate pollen comprised $18 \%$ of the total in Sample SW7Sept. Nearly all of the grains were found in the sea water samples, but a few were encountered in the sea-ice and diatom mat samples. Percent contributions by vesiculate taxa, porate or colpate pollen and vesiculate fragments for Sample SW7Sept are illustrated (Fig. 2). Pollen and spore population density per liter of sea water samples is listed (Table 3).

\section{Discussion}

Almost all of the pollen grains encountered were in the sea water samples; occurrences in diatom mat or sea-ice samples were rare (Table 2). We believe that this is due to transport pathways. It is quite plausible that the grains were transported via water masses such as the Arctic Current (Fig. 1). As mentioned earlier, the clockwise flow of the Arctic Current may play an important role in transporting 
Plate 1
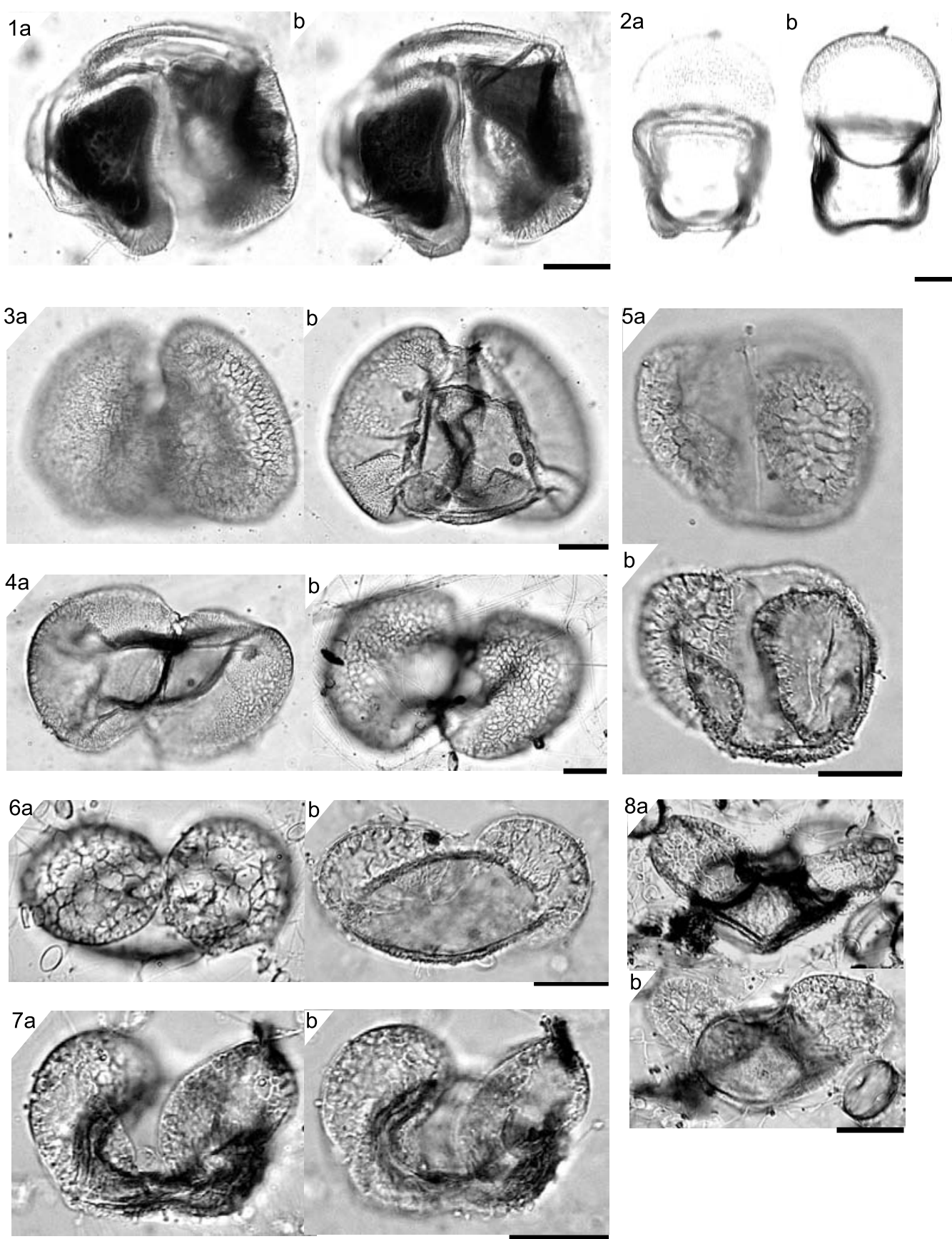

Plate 1. Photomicrograph of pollen with two focal levels. Scale bars equal to $20 \mu \mathrm{m}$. 1. Picea ("Touhi" in Japanese), SW7Sept. 2. Abies ("Momi" in Japanese), SW7Sept. 3-4. Picea, SW7Sept. 5. Pinus ("Matsu" in Japanese), SW25 Aug. 6-8. Pinus, SW7Sept. 
Plate 2
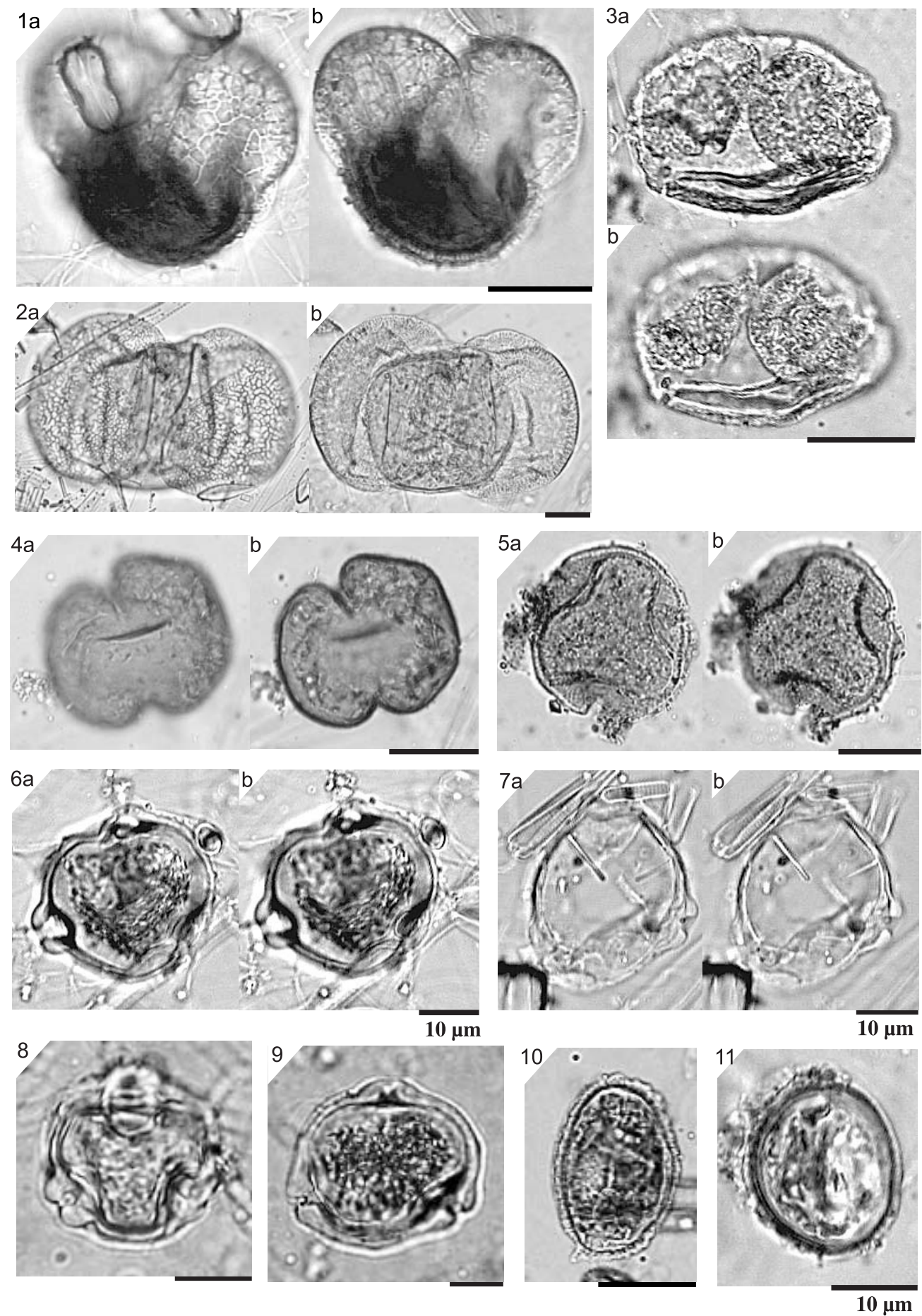

Plate 2. Photomicrograph of pollen and spores with two focal levels except for 8-11. Scale bars equal to $20 \mu \mathrm{m}$, except for figs. 6, 7 and 11, which are $10 \mu \mathrm{m}$. 1. Pinus, SW25Aug. 2. Pinus, SC14Aug. 3. Pinus, SW 7 Sept. 4. Colpate, SC25Aug. 5. Colpate, SW7Sept. 6. Triporate, SW7Sept. 7. Triporate, SC14Aug. 8. Triporate, SW25Aug. 9. Triporate, SC14Aug. 10. Monolete spore, DM14Aug. 11. Monolete spore, SW25Aug. 


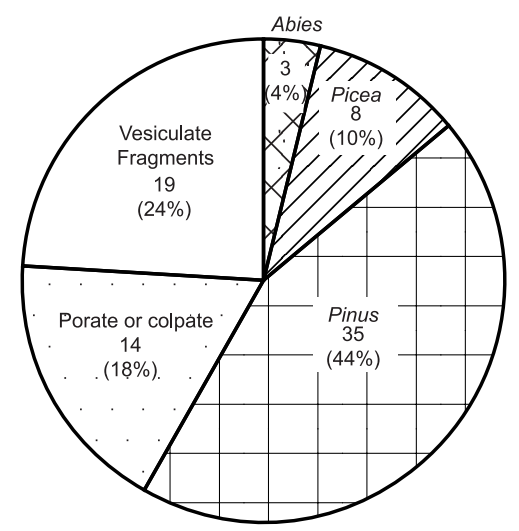

Fig. 2. Percent and raw count distribution of vesiculate, vesiculate fragments and porate/colpate pollen taxa (excluding spores) in Sample SW7Sept, the most abundant of all three SW samples. The numerals shown in the upper row represent raw microslide counts whereas those shown in the parentheses below represent percentages.

Table 3. Pollen and spore population density (No. liter ${ }^{-1}$ ) of the sea waters at each of the three sampled stations.

\begin{tabular}{|c|c|c|c|c|c|c|}
\hline \multicolumn{5}{|c|}{ Vesiculate } & Porate & Spore \\
\hline Sample Date & $a^{i e^{2}}$ & $p^{i e^{e v}}$ & pint & jest & $\mathrm{pot}^{\mathrm{O}^{\circ}}$ & 40 \\
\hline SW14Aug & 0 & 0.02 & 0.02 & 0 & 0 & 0.01 \\
\hline Ф SW25Aug & 0 & 0.37 & 0.50 & 0.62 & 0.62 & 0.75 \\
\hline 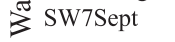 & 0.50 & 1.33 & 5.83 & 3.16 & 2.33 & 17.66 \\
\hline Ф TOTAL & 0.50 & 1.72 & 6.35 & 3.78 & 2.95 & 18.42 \\
\hline MEAN & 0.16 & 0.59 & 2.11 & 1.29 & 0.98 & 6.14 \\
\hline
\end{tabular}

suspended particles such as pollen into the central Arctic. While the geostrophic wind flows with high intensity on the perimeter of the Arctic Ocean, the chances of transporting significant amount of pollen and spores across the central Arctic Ocean are slim. Because the sampled stations were covered by seaice almost all of the year and hence direct input of air-born particles to sea water does not take place other than via sea-ice, the oceanic current is the most likely pollen conveyer (Fig. 3). Kawahata and Ohshima (2002) illustrate the lateral transport mechanism for pollen recovered from sediments on the Hess Rise, ca 3,000 km from the Japanese Islands, which are the nearest landmasses. Some pollen were advected by the Kuroshio Extension Current, which originates from the regions of the southern Japanese Archipelago and the East China Sea during Marine Isotope Stage (MIS) 6 (ca. 185 to $130 \mathrm{ka}$ ), MIS 4 (ca. 70 to $60 \mathrm{ka}$ ) and MIS 2 (ca. 25 to $11 \mathrm{ka}$ ). It is clear that they were not transported as aerosols by the Jet Stream winds because of the latitudinal miss-match of the taxa. Kawahata and Ohshima (2002) would have found Abies, Tsuga, Picea, Pinus, Betula, or Alnus (alder, "Hannoki" in Japanese) during the glacial stages, if the Jet Stream was responsible for transporting the taxa found in the Hess Rise core. In stead, they found Ephedra ("Maou" in Japanese) and Podocarpus (yew plum pine, "Maki" or "Nagi" in Japanese), pollen of the gymnosperm shrub, as typical taxa, providing significant evidence for transport by the oceanic current rather than the Jet Stream wind. Today's Kuroshio Current speed is ca. 3.7 to $5.5 \mathrm{~km} \mathrm{~h}^{-1}$ (Sakuda et al., 1999), corresponding to the transport time of ca. 22 to 33 days from the southern Japanese Islands or southern China to the Hess Rise in the North Pacific. Such a short advection time makes it possible for the pollen to reach the Hess Rise without being scavenged in the near surface waters. 


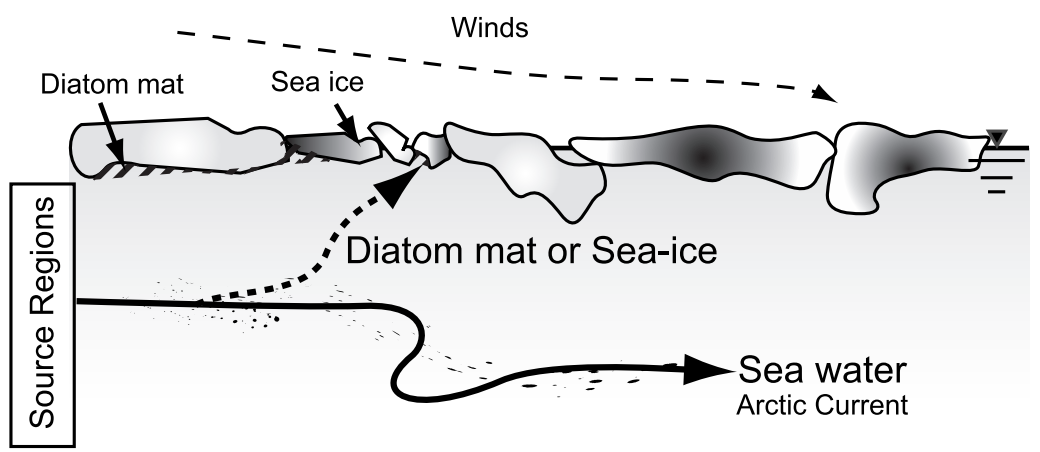

Fig. 3. Possible pathways (ocean currents and winds) for pollen grains and spores to reach the central Arctic Ocean.

In a review of palynomorph distribution in the northeast Pacific Ocean, Heusser and Balsam (1977) state that pollen abundances on the continental margin are a function of terrestrial vegetation, fluvial transport, and marine sedimentation. Concentrations of pollen taxa in marine sediment adjacent to rivers that drain areas in which the taxa grow suggests that fluvial transport is a prominent factor controlling pollen influx in the northeast Pacific Ocean, while relatively small amounts of pollen are delivered by eolian transport (Heusser and Balsam, 1977; 1985). Whereas abundances of pollen taxa, including Pinus and Picea, are related to distribution of these taxa on the adjacent continent, Pinus accounts for at least 30\% of the pollen in all of Heusser and Balsam's (1977) samples, including sites adjacent to areas where pine trees are absent. Furthermore, abundances of Pinus increase with distance from the coast, while abundances of other taxa decrease seaward. The extension of pine pollen beyond its terrestrial range and the seaward increase in abundance probably reflect transport of pine pollen by currents and hydrodynamic efficiency of pine pollen grains. Differential resistance to destruction may also be a factor in long-distance transport. Although morphologically similar to Pinus, vesiculate grains of Picea are apparently not as hydrodymanically efficient, as percentages of Picea in marine sediments are comparable to the importance of spruce in adjacent northern forests (Heusser and Balsam, 1977).

Alternatively, pollen can also be carried long distances by winds. Rousseau et al. (2005) documented pollen transport from North America to the Greenland via winds in spring 2003. They suggest that pollen of Pinus, Juglans (walnut, "Kurumi" in Japanese), Fagus (beech, "Buna" in Japanese) and others were advected by wind, reaching Greenland in two weeks. The following are the primary source regions for the pollen recovered from the Arctic Ocean: 1) Siberia, 2) Canadian high latitudes; 3) Coastal areas of North America facing the Pacific Ocean and the Bering Sea; and 4) coastal Northern Europe or the northern Atlantic Ocean. It is possible that the summer geostrophic wind transports particles from boreal forest or tundra in Siberia or the high latitudes of Canada (Fig. 3). However, the geostrophic wind blows around outer rim of the Arctic Ocean; the trajectory is confined between ca. latitude 60 or $70^{\circ} \mathrm{N}$ from west to east (Ganpo et al., 1982), and it does not usually blow diagonally across the central Arctic. In addition, the sampled area is covered by perennial sea-ice; it is difficult to transport the pollen grains by wind and subsequently deposit them into sea water masses under the sea-ice.

River systems around the Arctic Ocean play an important transport role prior to the possible advection of the pollen grains by the ocean current, in addition to direct air-born input from the terrigenous areas. For example, four major rivers drain Arctic Canada and Alaska: the Yukon, Kobuk, Colville, and Mackenzie Rivers. Siberia and northern Europe are drained by eight major rivers. From west to east, these are the Severnaya, Dvina, Pechora, Ob, Yenisei, Lena, Yana, 
Indigirka, and Kolyma rivers (Alexander, 1986). The Mackenzie River in Canada, for example, delivers pollen and spores to the Arctic Ocean. It can supply a large quantity of organic matter including spores, pollen grains and algae (Carrie et al., in press); its total particulate organic carbon (POC) flux is ca. 1 million ton $\mathrm{yr}^{-1}$ to the Mackenzie Delta. A small part of this flux can possibly exit to the Canada Basin, analogous to what Kulikov (1961) found: $1.5 \%$ of particles discharged to the Kara Sea were dispersed beyond the continental shelf into the Nansen Basin.

In addition, Boucsein et al. (2002) illustrate the flow-into process of organic matter to the Arctic Ocean during the last glacial stage to the Holocene. First, the river system works as the conveyer of organic carbon. In their study, the river systems include Ob, Yenisei, Khatanga, Anabar, Olenek, Lena and Yana rivers. Second, organic matter including pollen is advected by sea surface water circulation from these rivers to the edge of Eurasian continental margin of the Kara or Laptev Sea. This result does not conflict with the results of Kawahata and Ohshima (2002) in the Kuroshio Extension Current and Heusser and Balsam (1977) in the North Pacific Ocean. The vesiculate pollen grains that we observed were most likely delivered to the Arctic Ocean by these river systems, since the source areas are tundra or boreal forests of high latitude. Porate pollen and spores may be derived from the boreal forest, but some of these grains may have also been transported from the temperate zones further south although the chances of such a long distance transport may be small.

Strong pieces of evidence suggesting advection of suspended particles derived from river runoff into the central Arctic Ocean were discussed in detail by Schlosser et al. (1995). According to Schlosser et al. (1995), the upper waters of the Arctic Ocean can be divided into the Polar mixed layer (30 to $50 \mathrm{~m}$ depth) and the halocline (30 to $50 \mathrm{~m}$ to about $200 \mathrm{~m}$ depth). Waters in the halocline are formed during winter freezing in the marginal shelf seas and are advected into the central Arctic basins. They cited the conclusion reached by Westerlund and Öhman (1992) that the high surface concentrations of rare earth elements observed at $86^{\circ} \mathrm{N}$ in the Eurasian Basin were due to river runoff. Furthermore, they suggested a higher fraction of river-runoff in the surface waters of the Canadian Basin than the Nansen and Amundsen Basins.

When we consider advective transport of pollen with relatively small amont of transit time it may be advantageous for us to consider some sort of density currents. An analogous lateral transport process was shown for POC in the Okhotsk Sea Intermediate Water (OSIW), based on samples from two layered sediment traps deployed at two sites in the Okhotsk Sea (Ternois et al., 2000; Okazaki et al., 2003a). During winters in the Okhotsk Sea, brine water is rejected due to sea-ice formation and thus the dense OSIW is formed on the northwest continental shelf in the vicinity of the Amur River mouth. The OSIW is rich in POC content and hence it supports production of microbial biomass which in turn supports a prosperous population of Cycladophora davisiana, a radiolarian taxon that dwells in the OSIW (Okazaki et al., 2003a, b). An analogous process might explain the pollen and spores retrieved from the Arctic Ocean.

Scavenging processes, particularly those which are mediated by organisms, is known to remove the bulk of marine suspended particles within a short span of time and hence making the upper water column relatively free of "old" particles. The result of the scavenging is relatively rapid particle sinking towards sea-floor (Honjo et al., 2008). This makes it difficult to transport particles thousands of km away from source regions when sufficient amount of time is available for scavenging. The case with the Kuroshio Extension transport mentioned above is an unusual example with extremely rapid advection of the water masses. In the central Arctic Ocean because of the perennial sea-ice cover the scavenging process may be low effective in removing suspended particles in the upper water column due to expected less population density of zooplankton (e.g., Kosobokova and Hirche, 2000) or other organisms responsible for the scavenging process. Such low zooplankton populations stem from the ice cover which blocks bulk of the incoming incident solar radiation which in turn suppresses high population growth of phytoplankton (Booth and Horner, 1997). 
Cell density of pollen grains without mineral shells is less than, for example, siliceous phytoplankton such as diatoms with silica frustules. This makes pollen and spores more likely to be transported afloat for a longer distance than the shell bearing plankton counterparts. The former tends to float more than the latter in a given water mass. It may be that the pollen and spores could have been transported for a long distance along a certain density surface without being removed by biota underneath the perennial sea-ice in the Arctic Ocean. This can well be the case for what we have observed in the central Arctic Ocean.

Pollen of Pinus pumila can be distinguished by relatively thick part of the central body, which makes it similar to some species of Podocarpus. Pinus pumila is common in the boreal forest of Russia, but Podocarpus is relatively rare in the northern hemisphere. It can be found, for example, in the southern half of Japan and southern China. We tentatively conclude the absence of Podocarpus in our samples. While it is unlikely, if Podocarpus is determined to be indeed present in a future study, then we need to establish the transportation path as it is an unexpected element of the Arctic Ocean palynoflora indicative of very long distance transport by ocean currents or winds. In the Quaternary sediments in the ACEX cores, pollens (Pinus and Picea) were observed with minor abundance (Backman et al., 2006). If the reported vesiculate grains indeed included Podocarpus, it will be useful proxy of water connections between the Arctic and the North Pacific via the Bering Strait and the Bering Sea.

\section{Summary}

1. The pollen and spores encountered in the central Arctic samples included 227 grains and fragments. The dominant pollen taxa are vesiculate type: Pinus (pines, "Matsu" in Japanese), Picea (spruce, "Touhi" in Japanese) and Abies (fir, "Momi" in Japanese). Some porate, colpate grains and spores are also present.

2. Vesiculate pollen dominates the assemblages, comprising $58 \%$ in the sea water sample collected on 7 September 2004 at the North Pole. Porate pollen also contributed significantly $(18 \%)$ in this sample.

3. Almost all of the pollen grains were found in sea water samples, whereas only small numbers occurred in diatom mat and sea-ice samples. These pollen were likely to have been transported from tundra or boreal forest regions of Siberia or Canada by the drainage of river systems into the marine realm, and subsequently transported by the Arctic Current into the central Arctic Ocean.

4. Among the taxa belonging to the genus Pinus, Pinus pumila dominated the assemblages. Pinus pumila is very common in Siberia and hence it is not surprising that it is the dominant taxon in the Arctic Ocean assemblages. However, some Pinus taxa are very similar to the taxa belonging to genus Podocarpus. While we tentatively conclude the absence of Podocarpus in the Arctic samples, a further confirmation is warranted in the future.

\section{Acknowledgements}

This work is based on the samples collected on board ice breaker R/V Oden during IODP Arctic Coring Expedition (ACEX) 302. We thank the co-chief scientists Prof. Jan Backman of Stockholm 
Univ. and Prof. Kate Moran of Univ. Rhode Island and the ACEX scientific party as well as the captain and crew who provided opportunities for us to sample the useful materials on board R/V Oden. Special thanks are due to Dr. Henk Brinkhuis of Univ. Utrecht who kindly provided diatom mat sample of 12 August 2004 and to Dr. Jonaotaro Onodera of Kochi Univ. and Dr. Itsuki Suto of Nagoya Univ. for their collaborative sampling effort with the second author on board R/V Oden. We thank the critical information needed for discussion provided by Prof. Emeritus Kyo Matsuda of Hokkaido Univ., Prof. Emeritus Akihito Kawamura of Mie Univ., and Dr. Masanobu Yamamoto of Hokkaido Univ. Dr. Shiro Nishida of the Nara University of Educations and Dr. J. Onodera kindly reviewed the manuscript and gave us critical comments. We thank the Miyazaki Insurance Firm \& Co. Ltd., CEO Hisako Miyazaki and Vice President Masako Ito for their help and private financial support as scholarship fund for the senior author. This work has been benefited using the following funding to the second author: MEXT Grants-in-Aid-for Scientific Research B1 Project No. 13440152, B2 Project No. 15310001 and JSPS B Project No. 17310009.

\section{References}

Aagaard, K., Swift, J.H., and Carmack, E.C. (1985). Thermohaline circulation in the Arctic Mediterranean Sea. Journal Geophysical Research, 90 (C3), 4833-4846.

Alexander, V. (1986) Arctic Ocean Pollution. Oceanus, Vol. 29, No.1, 31-35.

Alexeyev, V.A., Birdsey, R.A., Stakanov, V.D., and Korotkov, I.A. (2000) Carbon Storage in the Asian Boreal Forests of Russia. Fire, Climate Change, and Carbon Cycling in the Boreal Forest. Ecological Studies, 138, 239-237.

Andreev, A., Forman, S. L., Ingólfsson, Ó., and Manley, W. F. (2006) Middle Weichselian environments on western Yamal Peninsula, Kara Sea based on pollen records. Quaternary Research, 65, 275-281.

Bachman, J., Moran, K., McInroy, D.B., Mayer, L.A. and the Expedition 302 Scientists. (2006) Expedition 302 [DVD]. Proceedings of the Integrated Ocean Drilling Program, 302, doi:10.2204/iodp.proc.302.2006.

Booth, B.C., and Horner, R.A. (1997) Microalgae on the Arctic Ocean Section, 1994: species abundance and biomass. Deep-Sea Research II, 44: 1607-1622.

Boucsein, B., Knies, J., and Stein, R. (2002) Organic matter deposition along the Kara and Laptev Seas continental margin (eastern Arctic Ocean) during last deglaciation and Holocene: evidence from organic geochemical and petrographical data. Marine Geology, 183, 67-87.

Carrie, J., Sanei, H., Goodarzi, F., Stern, G., and Wang, F. Characterization of organic matter in surface sediments of the Mackenzie River Basin, Canada. International Journal of Coal Geology (in press).

Fowell, S. J., Hansen, B.C. S., Peck, J. A., Khosbayar, P., and Enebish, G. (2003) Mid to late Holocene climate evolution of the Lake Telmen Basin, North Central Mongolia, based on palynological data. Quaternary Research, 59, 353-363.

Ganpo, K., Tanaka, M., and Tokioka, T. (1982) Circulation of Atmosphere. Tokyo University Press, 256 pp. (in Japanese).

Gajewski, K., Garneau, M., and Bourgeois, J., C. (1995) Paleoenvironments of the Canadian high arctic derived from pollen and plant macrofossils: Problems and potentials. Quaternary Science Reviews, 14, 609-629.

Heusser, L. E., and Balsam, W.L. (1977) Pollen Distribution in the Northeast Pacific Ocean. Quaternary Research, 7, 45-62.

Heusser, L. E., and Balsam, W.L. (1985) Pollen sedimentation in the northwest Atlantic: effects of 
the western boundary undercurrent. Marine Geology, 69. 149-153.

Honjo, S., Manganini, S.J., Krishfield, R.A., and Francois, R. (2008) Particulate Organic Carbon Fluxes to the Ocean Interior and Factors Controlling the Biological Pump: A Synthesis of Global Sediment Trap Programs Since 1983. Progress in Oceanography, 76, 217-285.

Kawahata, H., and Ohshima, H. (2002) Small latitudinal shift in the Kuroshio Extension (Central Pacific) during glacial times: evidence from pollen transport. Quaternary Science Reviews. 21, 1705-1717.

Kosobokova, K., and Hirche, H.-J. (2000) Zooplankton distribution across the Lomonosov Ridge, Arctic Ocean: species inventory, biomass and vertical structure. Deep Sea Research I, 47(11), 2029-2060.

Kulikov, N. N. (1961) Sedimentation in the Kura Sea. Moscow. Translated by US Naval Oceanographic Office, Washington, D. C., 1976, 16 pp.

Matsushita, M. (1993) A Handbook of Quaternary Research, Vol. 2, 228-235. Japan Association for Quaternary Research, Univ. of Tokyo Press, 556 pp. (in Japanese)

McAndrews, J., H. (1984) Pollen Analysis of the 1973 Ice Core from Devon Island Glacier, Canada. Quaternary Research, 22, 68-76.

Okazaki, Y., Takahashi, K.,Yoshitani, H., Nakatsuka, T., Ikehara, M., and Wakatsuchi, M. (2003a) Radiolarians under the seasonally sea-ice covered conditions in the Okhotsk Sea: Flux and their implications for paleoceanography, Mar. Micropaleontol, 49, 195-230.

Okazaki, Y., Takahashi, K., Nakatsuka, T., and Honda, M. C. (2003b) The production scheme of Cycladophora davisiana (Radiolaria) in the Okhotsk Sea and the northwestern North Pacific:implication for the paleoceanographic conditions during the glacials in the high latitude oceans. Geophysical Research Letters, 30 (18), 1939, doi:10.1029/2003GL018070.

Peck, J. A., Khosbayar, P., Fowell, S. J., Pearce, R. B., Ariunbileg, S., Hansen, C. S. B., and Soninkhishig, N. (2002) Mid to Late Holocene climate change in north central Mongolia as recorded in the sediments of Lake Telmen. Palaeogeography, Palaeoclimatology, Palaeoecology, 183, 135-153.

Rousseau, D, -D., Schevin, P., Duzer, D., Cambon, G., Ferrier, J., Jolly, D., and Poulsen, U. (2005) Pollen transport to southern Greenland: new evidences of a late spring long distance transport. Biogeosciences Discussions, 2, 1-19.

Sakuda, M., Kawanishi, T., Hotta, K., and Masuda, K. (1999) Ocean Environmentology. Kyoritsu Printing, Co., 169 pp. (in Japanese)

Schlosser, P., Swift, J.H., Lewis, D., and Pfirman, S.L. (1995) The role of the large-scale Arctic Ocean circulation in the transport of contaminants. Deep-Sea Research II, 42(6), 134-1367.

Shimoyama, S., Matsumoto, N., Kuroda, T., Takemura, K., Hamamoto, R., Mizota, C., Faure, K., and Nishida, T. (1995) Paleoenvironment of the Late Pleistocene, in the Chikushi Plain, West Japan. Science Report of Department of Earth and Planetary Science, Kyushu University, 19(1), 53-79. (in Japanese, with English Abstract)

Takahashi, K., Onodera, J. and Katsuki, K. Significant populations of seven-sided Distephanus (Silicoflagellata) in the sea-ice covered environment of the central Arctic Ocean, summer 2004. In: M. Kaminski and K. Takahashi, Guest Editors, IODP Expedition 302 ACEX Special Volume, Micropaleontology (in press.).

Ternois, Y., Kawamura, K., Ohkouchi, N., and Keigwin, L.D. (2000) Alkenone sea surface temperature in the Okhotsk Sea for the last 15 kyr. Geochemistry Journal, 34, 283-293.

Wirth, C. (2005) Fire Regime and Tree Diversity in Boreal Forests: Implication for the Carbon Cycle. Forest Diversity and Function. Ecological Studies, 176, 309-344.

Westerlund, S., and Peder, Ö. (1992) Rare earth elements in the Arctic Ocean. Deep-Sea Research, 39, 1613-1626. 